\title{
Satisfaction as Mediators of the Relationship between Motivation and Loyalty of Diving Tourists to Bali
}

\author{
I Wayan Suardana, I Komang Gde Bendesa, and Made Antara
}

\author{
School of Postgraduate Study \\ Doctorate Degree in Tourism Udayana University \\ Coressponding author: suar.dana@yahoo.co.id
}

\section{ARTICLE INFO}

Received

20 October 2013

Accepted

28 February 2014

Available online

10 March 2014

\begin{abstract}
This study was conducted to determine the relationship between extrinsic motivation, satisfaction with the product loyalty and loyalty to the service provider either directly or indirectly. Intrinsic and extrinsic motivations of tourists were used as predictors in determining the tourist loyalty through satisfaction. The model adopted was tested on 250 travelers who had ever been diving in Bali with structural equation modeling (SEM). The empirical results showed that the causal relationship between intrinsic motivation, extrinsic motivation, and satisfaction with service loyalty and product loyalty could be confirmed. Satisfaction became a full media on the relationship between motivation and loyalty. In this model, it could be proved that there was a positive effect of service loyalty on product loyalty. This study contributes to the development of tourist loyalty which should pay attention to tourist satisfaction arising from intrinsic and extrinsic motivation of tourists. Tourist strong motivation to do diving would have an impact on the perceived satisfaction so that tourists have loyalty in service provider and loyal to the diving tourism product shown by intending to return to Bali and would recommend it to others.
\end{abstract}

Keywords: motivation, satisfaction, product loyalty and service loyalty.

\section{Introduction}

\section{Background}

Diving is a popular marine tourism activity in countries that have the structure of the island nation and has coral reefs with diverse marine biota. Diving becomes a tourist activity for someone who has a deep-sea diving expedition motivation. These tours directly or indirectly have a positive impact on the efforts of conservation of coral reefs and the benefits in improving the economy of coastal communities. Although diving becomes one of the tourist attractions liked by tourists, but little information related to postpurchase behavior of divers or after the use of the diving tourist attractions.

http://ojs.unud.ac.id/index.php/eot
According to Singh (2006), a satisfaction constitutes overall attitude of tourists towards the product and service providers, or emotional reactions of tourists to the difference between the expected and accepted reality. Tourist satisfaction is realized from experience during his visit which is based on the motivation of his visit (Yoon and Uysal, 2005). In some cases tourist behavior proves to be a strong predictor of satisfaction in determining the satisfaction of tourists (Correia, Oom do Valle and Moço, 2007). One theory that could explain the relationship between motivation and satisfaction is the Self-Determination Theory (Schüler, Sheldon and Fröhlich, 2010). Deci and Ryan (2000), developed the Self-Determination Theory to investigate how different types of motivation generate different levels of self-determination. 
This theory is one multi dimentional framework, consisting of two motivations, intrinsic motivation and extrinsic motivation. This theory explains that the strong intention of a person in acting can be seen with real action to predict and identify behaviors (Schüler, Sheldon and Fröhlich, 2010). Intrinsic motivation shown by someone would make him interested in an activity and a sense of comfort when doing so and based on sincerity whereas extrinsic motivation is an activity undertaken by individuals because of pressure from outside parties. Travelers will realize the motivation to achieve satisfaction (Vallerand, 2007). Motivation of individuals, especially the intrinsic motivation can make satisfaction for individuals when sharing their knowledge (Gagné and Deci, 2005). According to Correia, Oom do Valle and Moço (2007), motivation fosters loyalty to the service provider at the destination. Travelers visit a destination because of the services provided by the service provider developing extrinsic motivation that gradually increases intrinsic motivation.

In the context of tourist behavior, tourist satisfaction can provide improved traveler loyalty (Chumpitaz Caceres and Paparoidamis, 2007). According to Ünlüönen, Kiliçlar and Yüksel (2011) product loyalty is the result of a tourist destination for tourists which creates benefits that they will maintain or intend to visit again. Loyalty to the service provider is commitment to re-use the same service consistently despite in the future situational influences have the potential to cause switching behavior (Alegre and Cladera, 2009). Some researchers have linked the role of satisfaction in the relationship between motivation and loyalty of a tourist. Yoon (2002) describes the research model that links between motivation, satisfaction, and loyalty. The analysis used is a structural equation model (SEM). This study distinguishes motivation into intrinsic motivation and extrinsic motivation. The assumed models can be accepted. In understanding the tourist loyalty, satisfaction is very important role as mediating the relationship between motivation and loyalty products and loyalty to the service. Meanwhile tourist satisfaction is formed out of motivation that comes from within the individual (intrinsic) and external (extrinsic) (Yoon and Uysal, 2005). The relationship

http://ojs.unud.ac.id/index.php/eot between satisfaction and loyalty seems to be more complex than expected. This change in emphasis to the relational marketing has expanded predictor than loyalty (Fullerton and Taylor, 2000; Chumpitaz Caceres and Paparoidamis, 2007). Kim et al. (2011) warns that satisfaction is very important in maintaining the level of tourist loyalty, but not a guarantee that tourists will be loyal. Satisfaction will measure how tourist expectations are met through a transaction, while loyalty measures how tourists are back into a destination partner. This phenomenon is important in the activity of special interest, that is, diving is a tourist activity at risk, where visitors really have to have the motivation to diving in Bali, which has an influence on their loyalty to return or recommending diving product in Bali to another person or the role of satisfaction is indirectly important in creating product loyalty. In this perspective, satisfaction is a mediator on the influence of motivation on loyalty (Garbarino and Johnson, 1999). So in building product loyalty and loyalty of service providers, the satisfaction is assumed to be the entry point. Customers should be encouraged to delight zone, where tourists have to get satisfaction and feel happy or excited, so it will lead to loyalty (Gnoth, Bigné and Andreu, 2006).

The variation in the results of an empirical study on the relationship between the variables of motivation, satisfaction and loyalty encourage the need for research on tourist loyalty which is distinguished between product loyalty and loyalty of service providers in the field of diving. Previous research in tourism has been approached with the concept of loyalty to the tourist destination from the perspective of the intention to repeat visits and recommend the destination to friends or relatives, but rule out the effect of relationship marketing and the value of the destinations that make up loyalty (Forgas, et al 2012). While previous studies have shown that the influence on the decision made by travelers to visit again, none of the identified motivation in influencing satisfaction and tourists' loyalty in diving. To fill the existing gap in the literature, it is proposed to develop a theoretical model which allows explaining the role of satisfaction in relation to the motivation of product loyalty and service loyalty. The purpose of this study was 1) to develop models 
of the effect of intrinsic motivation, extrinsic motivation, and satisfaction with loyalty of services and product loyalty of diving in Bali; 2) to analyze the role of satisfaction as mediating the influence of motivation on tourist loyalty diving in Bali.

\section{Methodology}

This study used survey research design. Therefore, the design and construct of a questionnaire were very important in determining the success of a survey. This study would identify and examine the causal relationship between one variable and another variable or search for a causal relationship between exogenous and endogenous variables so that this kind of research can be categorized into verificative, associational or correlational research. The experiment was conducted at development centers for diving in Bali, they are Sanur and Benoa areas, West Bali and Pemuteran areas, area of Nusa Penida, Tulamben area, and Candidasa area. The data collection was conducted during the month of July 2013 - June 2014.

Data collection for the study of intrinsic motivation variable (X1), extrinsic motivation (X2), satisfaction (X3), product loyalty (Y1), as well as service loyalty (Y2) used a questionnaire. The questionnaire contained a number of statements that were developed from the types of instruments. For the scale measurement, Likert scale was used in the form of a statement expression strongly disagree to strongly agree with the score of the numbers 1 to 5. Preparation of a questionnaire was based on the indicators that refer to the theory. The indicators used in this study are reflective indicators. In reflective models, manifest group variables associated with latent variables are assumed to measure indicators that manifest constructs. Characteristics of the variables measured in the reflective scale are the togetherness between the measuring indicators (common factor) (Hair et al., 2010). Variables and indicators used in this study are presented in Table 1. Testing the validity and reliability of the data showed all the indicators had correlation values above 3.0, Cronbach Alpha coefficients above 0.7 so that the indicator could be said to be valid and reliable. This research is quantitative research. The research data were primary data conducted in

http://ojs.unud.ac.id/index.php/eot the survey of 250 tourists diving in Bali. The determination of the number of samples was carried out by quota sampling. The distribution of questionnaire was conducted in clusters based on the proportion of tourist visits in five diving locations, i.e. 53 respondents in the area of Sanur and Benoa, 50 respondents in Region Candi dasa, 54 respondents in Tulamben area, 59 respondents in the area of Nusa Penida, and 34 respondents in the area of Menjangan Island and Pemuteran. The relationship between the variables of motivation intrinsic motivation, extrinsic motivation, satisfaction with product loyalty and loyalty of services used the analysis of Structural Equation Model (SEM) with the Analysis of Moment Structural (AMOS.6) and measurement of satisfaction mediating role in the relationship between motivation and loyalty was tested by Sobel Test.

Table 1. Variable, Indicator and Measurement Scale

\begin{tabular}{|c|c|c|c|c|c|}
\hline No & Variable & $\begin{array}{l}\text { Number } \\
\text { of } \\
\text { indicators }\end{array}$ & & Indicator & Source \\
\hline 1 & $\begin{array}{l}\text { Intrinsic } \\
\text { motivati } \\
\text { on }\end{array}$ & 4 & 1. & $\begin{array}{l}\text { For } \\
\text { knowledge } \\
\text { To improve } \\
\text { the } \\
\text { competence } \\
\text { of diving } \\
\text { To establish } \\
\text { a relation or } \\
\text { social } \\
\text { cohesion } \\
\text { For } \\
\text { sensation or } \\
\text { relaxation }\end{array}$ & $\begin{array}{l}\text { Adapted from (Ryan } \\
\text { and Deci (2000); } \\
\text { Vallerand, et al, } \\
\text { (1992); Beggs and } \\
\text { Elkins (2010). }\end{array}$ \\
\hline \multirow[t]{3}{*}{2} & \multirow[t]{3}{*}{$\begin{array}{l}\text { Extrinsic } \\
\text { Motivati } \\
\text { on }\end{array}$} & \multirow[t]{3}{*}{4} & 1. & $\begin{array}{l}\text { To improve } \\
\text { diving } \\
\text { achievemen } \\
\text { t. }\end{array}$ & \multirow[t]{3}{*}{$\begin{array}{l}\text { Adapted from (Correia } \\
\text { and Valle, 2007). }\end{array}$} \\
\hline & & & 2. & $\begin{array}{l}\text { Diving di } \\
\text { Bali gets } \\
\text { adequate } \\
\text { facilities }\end{array}$ & \\
\hline & & & 3. & $\begin{array}{l}\text { Bali has } \\
\text { underwater } \\
\text { diversity. } \\
\text { Following } \\
\text { an } \\
\text { invitation of } \\
\text { a friend }\end{array}$ & \\
\hline \multirow[t]{2}{*}{3} & \multirow[t]{2}{*}{$\begin{array}{l}\text { Tourist } \\
\text { satisfacti } \\
\text { on }\end{array}$} & \multirow[t]{2}{*}{6} & 1. & $\begin{array}{l}\text { Diving is a } \\
\text { main choice } \\
\text { in travelling } \\
\text { Experience } \\
\text { gained is } \\
\text { precisely } \\
\text { the same as } \\
\text { expected, }\end{array}$ & \multirow[t]{2}{*}{$\begin{array}{l}\text { Adapted from Szuster, } \\
\text { (2011); Gallarza and } \\
\text { Saura, (2006); Musa } \\
\text { (2002) }\end{array}$} \\
\hline & & & & $\begin{array}{l}\text { On the } \\
\text { whole }\end{array}$ & \\
\hline
\end{tabular}




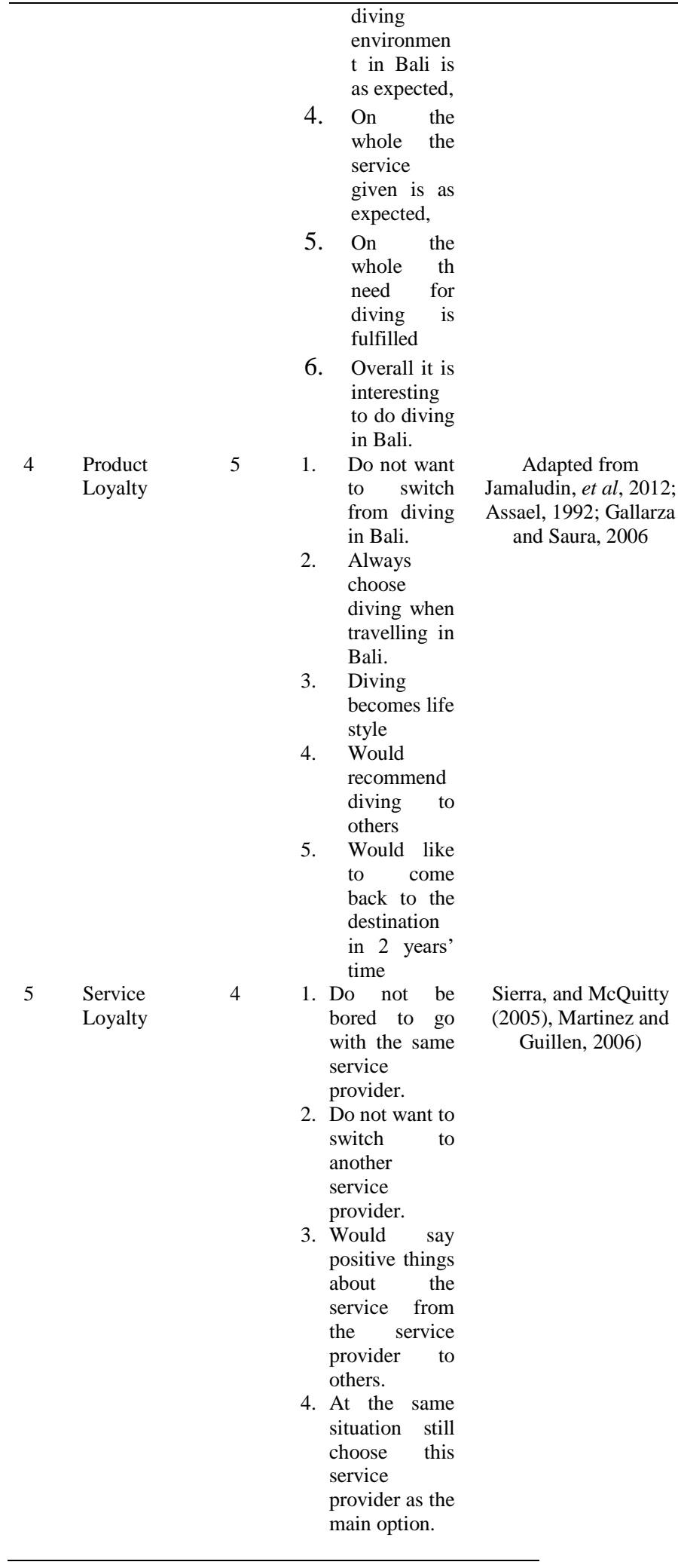

\section{Results and Discussion}

The result of the analysis on 250 respondents who did diving tours showed that Bali has specific characteristics of diving and potentially develop in the future. The dominant tourists diving in Bali came from

http://ojs.unud.ac.id/index.php/eot
Europe (33,2\%), Australia (32\%), and Asia $(21,6 \%)$ and America $(13,2 \%)$. The dominant gender was male respondents $(61,6 \%)$, and $38,4 \%$ female. Travelers who dived in Bali were the beginning divers category "picnicers" with the age of 28-37 years as many as 58,8\%, aged 18-27 years were 38\%, 38-47 years $3,6 \%$. Tourists who did diving had dominantly worked $(74,8 \%)$ and the average level of education was that they already graduated from college $(86 \%)$. Based on the experience level of diving, onthe average the tourists already had a diving experience of 1-5 years $(43,6 \%)$, The ones internationally certified 1 at the intermediate level (45,6\%), advaced (36\%), rescue $4,8 \%$ ), the dive master $(3,2 \%)$. Tourists who were diving in Bali were repeater tourists with lengh of stay of 4-5 days and the time spent to dive was an average of 1-2 hours. Tourists chose to stay at five-star hotels and the visit pattern was in group with friends whose number was 3-4 people.

\section{Effect of Intrinsic Motivation, Extrinsic Motivation, Satisfaction with Service Loyalty and Product Loyalty}

Models adopted in this study consisted of variables that include intrinsic motivation variable (X1), extrinsic motivation (X2), satisfaction (X3), product loyalty (Y1), as well as loyalty to the service provider (Y2). Assumptions that must be met prior to SEM analysis were the assumption of normality, the absence of outliers, and linearity. Normality test results had been met with critical value $\mathrm{Z}$ count for $\alpha 5 \%$ is equal to 1.96 . Mahalanobis distance was evaluated using a value of 128,565. Mahalanobis distance to the most distant point of observation is the respondent to 175 with a value $\mathrm{Md}=87,069$. When compared with the value of 150,7 to the value of $\mathrm{Md}$ point of 175 th $<128,565$, it was concluded that all points of observation were not an outlier. Tests for the linearity assumption were conducted by Curve Fit method. Linearity test results showed all linear models were significant because the value of Sig $<0,05$ therefore it was concluded that the assumption of linearity had been fulfilled. The test results of goodness of fit overall models were according to the results of SEM analysis, to determine whether hypothetical model was supported by empirical data, it is presented in Table 2. 
Tabel 2. Test Results of Goodness of Fit Overall Model

\begin{tabular}{llcc}
\hline \multicolumn{1}{c}{ Criteria } & $\begin{array}{c}\text { Cut-off } \\
\text { value }\end{array}$ & Model Result & Remaks \\
\hline Khi & Small & 347,938 & Good Model \\
Square & & & \\
p-value & $\geq 0,05$ & 0,060 & \\
CMIN/DF & $\leq 2,00$ & 1,225 & Good Model \\
GFI & $\geq 0,90$ & 0,912 & Good Model \\
AGFI & $\geq 0,90$ & 0,882 & Moderate \\
TLI & $\geq 0,95$ & 0,950 & Good Model \\
CFI & $\geq 0,95$ & 0,960 & Good Model \\
RMSEA & $\leq 0,05$ & 0,030 & Good Model \\
\hline
\end{tabular}

Source: processed data (2014)

The testing results of model suitability (Goodness of Fit Model) showed that X2 = 347,938 with a probability value of 0,060 which is above the significance limit of 0,05 . This indicates that the null hypothesis can be accepted. That is, there is no difference between the sample covariance matrix and population covariance matrix estimated and therefore this model is acceptable. Measurement index of model suitability GFI, AGFI, TLI, CFI, RMSEA, and CMIN /DF are in the expected range of values (Hair et al., 2010). Therefore SEM models in this research are suitable and feasible to be used, so interpretation can be made for further discussion.

Structural models involving many variables and paths among variables contain influence among variables that include direct effect, indirect effect and total effect (Ferdinand, 2002). The coefficient of each effect among variables is presented in Table 3 .

Tabel 3

\section{Effect of Direct, Indirect and Total Effects} of inter Variables

\begin{tabular}{|c|c|c|c|c|}
\hline Variable & $\mathrm{R}^{2}$ & $\begin{array}{l}\text { Direct } \\
\text { Effect }\end{array}$ & $\begin{array}{l}\text { Indict } \\
\text { Effect }\end{array}$ & $\begin{array}{l}\text { Total } \\
\text { Efect }\end{array}$ \\
\hline Effect on Satisfaction & 0,511 & & & \\
\hline $\begin{array}{l}\text { Intrinsic } \\
\text { motivation }\end{array}$ & & 0,580 & & 0,580 \\
\hline $\begin{array}{l}\text { Extrinsic } \\
\text { motivation }\end{array}$ & & 0,411 & & 0,411 \\
\hline Effect on Service Loyalty & 0,364 & & & \\
\hline $\begin{array}{l}\text { Intrinsic } \\
\text { motivation }\end{array}$ & & - & 0,325 & 0,325 \\
\hline Satisfaction & & 0,556 & 0,125 & 0,567 \\
\hline Effect on Product Loyalty & 0,524 & & & \\
\hline $\begin{array}{l}\text { Intrinsic } \\
\text { motivation }\end{array}$ & & $-0,001$ & 0,398 & 0,344 \\
\hline $\begin{array}{l}\text { Extrinsic } \\
\text { motivation }\end{array}$ & & 0,003 & 0,288 & 0,291 \\
\hline Satisfaction & & 0,445 & 0,242 & 0,687 \\
\hline Service loyalty & & 0,341 & - & 0,265 \\
\hline
\end{tabular}

http://ojs.unud.ac.id/index.php/eot
Based on those in Table 3, it is known that satisfaction has a very important role in influencing loyalty. Satisfaction in total accounted for 0,687 of the product loyalty. The significance of direct effect between variables is presented in Table 4.

\section{Tabel 4. Structural Model of SEM Results:}

\section{Direct Effect}

\begin{tabular}{|l|c|c|c|}
\hline \multicolumn{1}{|c|}{$\begin{array}{c}\text { Relationship between } \\
\text { variables }\end{array}$} & $\begin{array}{c}\text { Std } \\
\text { coefficient }\end{array}$ & P-value & Remaks \\
\hline $\begin{array}{l}\text { Intrinsic Motivation } \\
(\mathrm{X} 1) \rightarrow \text { Satisfaction } \\
(\mathrm{X} 3)\end{array}$ & 0,580 & 0,000 & Significant \\
\hline $\begin{array}{l}\text { Intrinsick Motivation } \\
(\mathrm{X} 1) \rightarrow \text { Product } \\
\text { Loyalty (Y1) }\end{array}$ & $-0,001$ & 0,989 & $\begin{array}{c}\text { Non- } \\
\text { significant }\end{array}$ \\
\hline $\begin{array}{l}\text { Extrinsic Motivation } \\
(\mathrm{X} 2) \rightarrow \text { Satisfaction } \\
(\mathrm{X} 3)\end{array}$ & 0,411 & 0,000 & Significant \\
\hline $\begin{array}{l}\text { Satisfaction (X3) } \rightarrow \\
\text { Product Loyalty (Y1) }\end{array}$ & 0,445 & 0,002 & Significant \\
\hline $\begin{array}{l}\text { Satisfaction (X3) } \rightarrow \\
\text { Service Loyalty (Y2) }\end{array}$ & 0,556 & 0,000 & Significant \\
\hline $\begin{array}{l}\text { Service Loyalty (Y2) } \\
\text { Product Loyalty } \\
\text { (Y1) }\end{array}$ & 0,341 & 0,002 & Significant \\
\hline
\end{tabular}

Source: Processed data, 2014.

Graphically it is presented as follows:

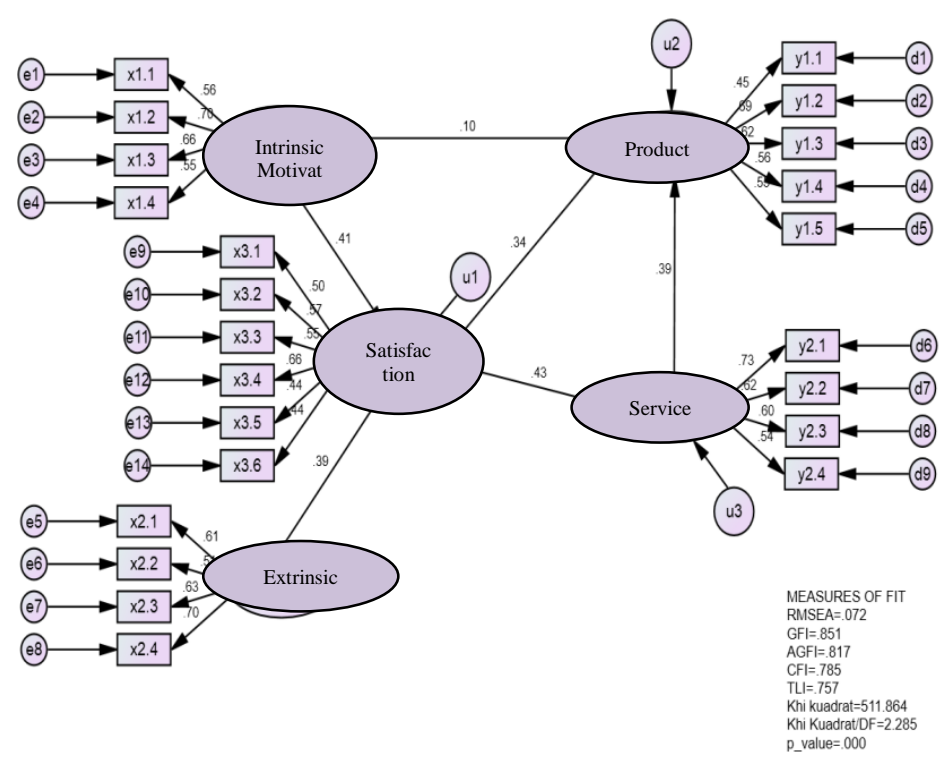

Figure 1. Structural models of SEM Results

Based on Table 2, the results of hypothesis testing can be presented as follows:

1. Intrinsic motivation has a positive and significant impact on satisfaction with $\mathrm{p}=$ $0,000(<0,05)$ with a coefficient of 0,580 . 
This means that there is a significant relationship between intrinsic motivation and satisfaction. This also means that the higher the intrinsic motivation, the higher the satisfaction and vice versa. This research can confirm the findings of Yoon and Uysal (2005); Lee (2009); Lee and Liu (2009), the effect of intrinsic motivation provides a strong influence on satisfaction. Four indicators of intrinsic motivation are for knowledge, for a skill/competency, to relationships/social cohesion, and to feel the sensation of stimulation. In diving, motivation knowledge or wanting to get new things becomes the main motivation for tourists diving in Bali. This study also reinforces the study results of Aziz and Ariffin (2009); Esichaikul (2012), the determination of the behavior of tourists visiting tourist destinations is analyzed by individual behavior through motivation and satisfaction received at the destination. Lee and Liu (2009); Schüler, Sheldon and Fröhlich (2010) who focus on a particular sub-competency of internal competencies contributes to the satisfaction level of the individual. This study also successfully developed the findings of Gnoth, Bigné and Andreu (2006) in the social aspects of tourism, tourist behavior based on motives strengthen relationships psychologically and sociologically giving positive effect on satisfaction obtained during travelling and the decision of travelling back to the destination.

2. Intrinsic motivation has no significant influence on product loyalty with $\mathrm{p}=0,989$ $(>0,10)$. This means there is no significant relationship between intrinsic motivation and product loyalty. This also means that the level of intrinsic motivation will not affect the level of product loyalty. This finding is contrary to the findings of Yoon and Uysal (2005) who find intrinsic motivation to have a significant direct effect on loyalty. Tourist loyalty which is influenced by the strength of a strong motivational force has no effect in the absence of services that make people reach their goal, i.e. satisfaction. Likewise Coreaia and Valle (2007), the results are tourist intrinsic motivation does not influence significantly tourists' intention to visit. Tourists want to go again to a tourist

http://ojs.unud.ac.id/index.php/eot destination for the need of stimuli to get away from their routines. Generally, the things to do to maintain intrinsic motivation are to arouse interest in activities to be done (Slavin, 2011: 124). Tourists are not only based on the intrinsic stimulus but there is a need for evidence prior to the tour experience, in addition to the need for the attributes that affect the destination. The importance of feedback or information provided by the operator during the process of diving is very important to foster a sense of curiousity of tourists to the activity undertaken.

3. Extrinsic motivation has a positive and significant impact on satisfaction with $\mathrm{p}=$ $0,000(<0,05)$ with a coefficient of 0,411 . This means that the higher the extrinsic motivation satisfaction will also be higher and vice versa. This study supports the results of Kim, Lee and Klenosky (2003); Lee (2009) the influence of external motivation can not be ignored and it has equally important influence in determining the satisfaction of tourists who traveled. The importance of understanding about a tourist destination of an advertisement, information from friends and also the existence of activities that must be followed in the tour is common in the tourism business. Additionally Setiadi (2010) emphasizes that tourists have extrinsic motivation, which is important to be rationally done by carefully determining the choice and the aim of travelling, then the perceived tendency is to be very satisfied. So this study found that the destination is very important attributes influencing tourist extrinsic motivation including uniqueness in the different dive sites from other locations. The uniqueness among others include Lembongan with its manta and sunfish, Tulamben with coral and ship wreck, Candidasa with big fish, and Menjangan Island with a variety of ornamental fish habitat.

4. Satisfaction has a positive and significant impact on product loyalty with $\mathrm{p}=0,004$ $(<0,05)$ with a coefficient value of 0,445 . This means that the higher the satisfaction, product loyalty will also be higher and vice versa. It supports research Valle et al. (2006), who finds that tourist satisfaction is 
one of the contributions of tourist loyalty intentions. Valle et al. (2006) limits research only on loyalty intentions. The findings of this study focused on the actual loyalty, i.e. tourists who had come, even up to 3 times having been to Bali. Satisfaction received during the experience of diving became a reason to return to diving although in different areas of diving spots. These results also support the research of Foster (1999); Baker and Crompton (2000); Yoon and Uysal (2005); Gnoth, Bigné and Andreu (2006); Um, Chon and Ro (2006); Yüksel and Yüksel (2007); Hui, Wan and Ho (2007); Jang and Feng (2007); Dmitrović et al. (2009); Kim, Kim and Kim (2009); Forgas-Coll et al. (2012), that the tourist satisfaction has significant effect on destination loyalty.

5. Satisfaction has a positive and significant impact on service loyalty with $\mathrm{p}=0,000$ $(<0,05)$ with the value of the coefficient value of 0,556 . This means that the higher the satisfaction, loyalty service providers will also be higher and vice versa. With positive emotions produce good satisfaction and loyalty to the service provider (Sierra and McQuitty, 2005). This study also reinforces the findings of Martínez and Guillén (2006); Salegna and Fazel (2011); Taleghani, Choobeh and Mousavian (2011) who reveal that there are significant satisfactions received by the consumer during the purchase which will result in increased loyalty to the service provider and wish to be serviced by the same provider.

6. Service Loyalty has a positive and significant impact on product loyalty with $\mathrm{p}$ $=0,002(<0,05)$ with a coefficient value of 0341. This means that the higher the service provider loyalty, product loyalty will also be higher and vice versa. These results reinforce the results of Sierra and McQuitty (2005) that the higher level of service loyalty will affect the emotions of the individual to a product. The important point of this study is to prove the concept of Pepe, Abratt and Dion (2011); Salegna and Fazel (2011) that increased service loyalty with branding can also have a positive effect on the increase of loyalty to the product. This study corroborates findings of Raj G. Javalgi and Moberg (1997), the implications of the service provider will have an impact on product loyalty. The greater the tourist intention to use the same services or recommend the same service providers to others gives an indication that the service provider has a good business and the potential to develop. The dimension of this attitude gives an indication that tourists will continue to use the same service provider or not.

\section{The Role of Satisfaction as Mediation in the Effect of Intrinsic Motivation, on Product Loyalty}

In addition to the test of direct effect on SEM also known is its indirect effect. Indirect effect is considred significant if two direct effects that shape them is significant. The results of the indirect effect are presented in Table 4:

Table 4. Structural Model of SEM Results: Indirect Effect

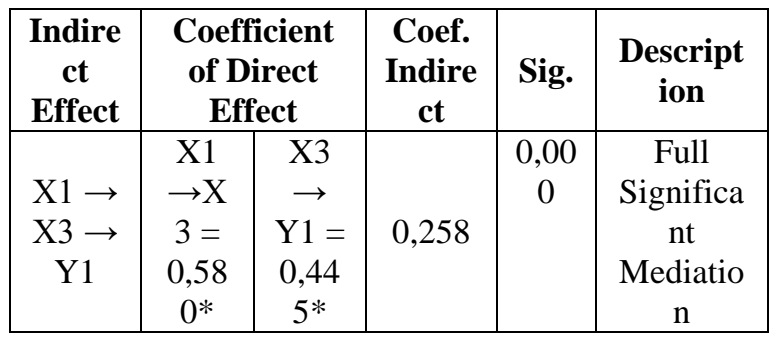

Source: Analysis results, 2014

Effect of mediation traveler satisfaction on the relationship between intrinsic motivation and loyalty of the product. Indirect effect between intrinsic motivation (X1) of the product loyalty (Y1) through satisfaction (X3), obtained $\mathrm{p}$ value of $0,000 \quad(<0.05)$ and the coefficient of indirect effect by 0258 it can be concluded that there is a significant indirect effect between intrinsic motivation (X1) to the loyalty of the product (Y1) through satisfaction (X3). This means that the higher the value of intrinsic motivation (X1), will affect the value of loyalty products (Y1) through satisfaction (X3). The mediating role of satisfaction is seen in the direct influence of intrinsic motivation to loyalty products, which is $-0,001$. Compared with the indirect effect of the obtained value is smaller than the direct effect of the indirect effect $(-0,258<0,286)$, so 
full of satisfaction as intrinsic motivation mediation with product loyalty. Sobel test calculations at $Z=2,846$ value can be greater than $\mathrm{Z}$ at the 0,05 level that is equal to 1,96 . It shows that tourist satisfaction act as a full and significant mediating variable in the relationship of intrinsic motivation and loyalty products.

This study provides empirical evidence that satisfaction becomes a mediator in building tourist intrinsic motivation to revisit their intention to diving in Bali. These findings corroborate the theory of self-determinant (Deci and Ryan, 2000), social exchange theory (Cropanzano and Mitchell, 2005) and the concept of loyalty (Jacoby and Kyner, 1973). Travelers expect any satisfaction to be assumed that if tourists are satisfied with the experience of traveling, they are willing to revisit their purpose and recommend their destination to others. In this context there has been a social transaction between the needs of tourists and tourism diving needs in the destination. Mutually beneficial transaction will benefit in relationship marketing aspect. Empirically, these findings corroborate the findings of Yoon and Uysal (2005), intrinsic motivation of tourists have an influence on tourist loyalty through satisfaction. Tourism of special interest has specific characteristics that require special knowledge and motivation to dive with a variety of activities undertaken including to protect against underwater environment (Barker and Roberts, 2004). Further mentioned that tourists who dive in diving tourism destination, in addition to having experience of diving they will look for a new challenge in an attempt to satisfy their desire.

Tourist satisfaction has the largest total effect of 0,687 to product loyalty. Satisfaction with service loyalty has the value 0,562 meaning that the product and service loyalty are predominantly influenced by satisfaction during the tour. For the lowest value, it is shown on the total effect of extrinsic to loyalty $(0,235)$. Travelers interested in diving again in Bali are not completely determined by destination factors such as the facilities, services, friends, and others but it is more determined by motivation arises from the tourists themselves. The model successfully developed in this research is a model of the

http://ojs.unud.ac.id/index.php/eot behavior of diving tourists through a causal relationship between intrinsic and extrinsic motivation, satisfaction, service loyalty and product loyalty. The linkage between intrinsic and extrinsic motivation and loyalty has been investigated by several researchers (Yoon and Uysal, 2005; Alegre and Cladera, 2009; Lee and Liu, 2009). The relationship between satisfaction and loyalty in tourism products and loyalty to the service provider also has been done a lot (Chow and Holden, 1997; Chumpitaz Caceres and Paparoidamis, 2007; Sanchez-Franco, 2009; Kim et al., 2011). Research on the relationship of loyalty and loyalty services on products was done by Pepe, Abratt and Dion (2011); Salegna and Fazel (2011). This study examined the mediating role of satisfaction, the influence of intrinsic and extrinsic motivation with product loyalty and loyalty to the service provider. The model formed expands the understanding of the antecedent of loyalty to the product, especially to contribute to the study of diving tourist behavior from the perspective of the theory.

An important finding of this study is indirect effect between intrinsic motivation and loyalty of the product. This result is contrary to the findings of Yoon and Uysal (2005); Alegre and Cladera (2009), motivation is considered as a perception that was brought from within him (Lee, 2009), so that only the attributes that are under the control of the service provider or operator of diving is measured or perceived by tourists. Diving becomes a unique form of tourism, sightseeing tours with knowledgeable and safety risks, so that intrinsic motivation becomes less important in predicting tourist loyalty directly, but a strong predictor on tourist satisfaction. Likewise, extrinsic motivation is not important in fostering loyalty in service provider, but being a predictor of the satisfaction. Travelers prefer the experience with diving, and wanting less demand for comfort (Perera, 2011). For diving, the satisfaction derived from participation of tourists on the product is more important than the satisfaction that comes from service providers. Experience gained in the form of satisfaction for diving will determine the decision to return or not to the same destination or recommend it to others. This finding is in line with the findings Joynathsing and Ramkissoon (2010), to foster 
intention of tourist behavior to return to the destination, the role of intrinsic and extrinsic motivation has to be accumulated into a positive attitude towards the destination. The attitude may be perceived as the experience gained during the tour.

Another important finding of this study is tourist satisfaction; tourists tend to greatly affect the product loyalty and loyalty to the service provider. The direct effect of satisfaction is found greater than the direct influence of trust and indirect effect of motivation on product loyalty. These results confirm the findings of several researchers (Gallarza and Saura, 2006; Martínez and Guillén, 2006; Um, Chon and Ro, 2006; Jang and Feng, 2007; Yuksel, Yuksel and Bilim, 2010; Forgas-Coll et al., 2012), that satisfaction tends to affect tourist loyalty on the product or the service provider. Effect of total satisfaction was found to contribute most to the creation of loyalty to products and loyalty to the service provider. However, Kim et al. (2011) warn that satisfaction is very important in maintaining the level of tourist loyalty, but not a guarantee that tourists will be loyal. Tourist satisfaction measures how tourist expectations are met through a particular transaction, while tourist loyalty measures how tourists can be back and want to become a partner provider of services or products such as recommending it to others. However there are some travelers who are not getting the satisfaction they will no longer diving in Bali. So the findings of this study confirm that satisfaction as a mediating role for the development of the relationship between motivation and loyalty, so the development of diving tourism in Bali continues to increase satisfaction as a precious value.

At the end part of this model, it was found that travelers who have a loyalty to the service provider have a positive effect on product loyalty. These findings also prove the concept developed by Salegna and Fazel (2011), that trend occurred in loyalty to service providers has an impact on increasing the loyalty of the product. Satisfaction and loyalty to the service for diving tourists are often related to the tourist intention to re-diving at the same destination and are willing to recommend the destination to others. Travelers who are loyal to the service provider make service providers as mediation on the product to be used. In this model, it can be demonstrated more clearly that the service provider acts as mediation on travelers trust relationship with tourist loyalty to diving tourism products in Bali. In confirmation with the previous tourism studies (Kim, Lee and Klenosky, 2003; Yoon and Uysal, 2005; Joynathsing and Ramkissoon, 2010), this study shows that intrinsic motivation, extrinsic motivation, and satisfaction as an important predictor in determining the tourist loyalty to service providers and loyalty to Bali tourism diving products.

Empirical model of this study proves the theory of relationship marketing (Berry, 1983). Long-term relationship that is mutually beneficial is created between product and service providers to tourists which becomes inseparable bond and interdependent. At this stage, loyalty is based on the high degree of satisfaction and tourists are personally involved with the service provider. This is in line with the opinion of Yoon and Uysal (2005); Gnoth, Bigné and Andreu (2006); Lee (2009) that the aspects that affect loyalty among others are emotion and motivation bonds, which means that tourists may be affected by a product which has developed its own charm. Travelers can be identified in a product, because a product can reflect the characteristics of the tourist. Bond that is created from a product is when tourists feel a strong bond with other consumers who use the same products or services. This is consistent with the findings of the characteristics of tourists that diving tourists have special characteristics as special interest tourists who have the same motivation to do diving. This motivation similarity is the strength of the relationship between tourists and diving products.

\section{Conclusion and Recommendation}

The whole findings of this study confirm positive and significant influence of motivation and loyalty of the product, except the relation of intrinsic motivation in product loyalty and extrinsic motivation on loyalty of services. Intrinsic motivation affects tourist loyalty through satisfaction. Extrinsic motivation affects service loyalty through 
satisfaction. Tourist satisfaction has largest contribution to the formation of the model of the relationship between motivation and product loyalty. This influence is the greatest influence after intrinsic motivation of tourists. This means that the product loyalty of tourists is predominantly influenced by tourist satisfaction formed from autonomous motivation of the tourists themselves. Overall satisfaction factors have a role as a full mediating the relationship intrinsic motivation and loyalty. Satisfaction factors, as a whole, have a role as a full mediation in the relationship of extrinsic motivation with loyalty to the service. Based on this we can conclude that tourist satisfaction is very important in ensuring tourist loyalty to products and loyalty to the service. Although in some studies, it is still a debate that satisfaction does not guarantee loyalty of tourists.

Thus, to increase the loyalty of tourists, the government and the service provider must maintain a good service by performing good control on diving spots and variation of the package has to be according to the characteristics of tourists, so the value of tourist satisfaction remain fulfilled. Providers and the government focus on enhancing the satisfaction of self-esteem formed thereby building a good image of the tourism product. However, further research needs to be done in order to distinguish between domestic and foreign tourists to know the market trend loyal to diving products in Bali. Researchers in the future needs to pay attention to perceived risk as variables that affect tourist satisfaction (Cheng and Lee, 2011).

\section{Acknowledgement}

Thanks to the Rector of Udayana University, Prof. Komang Bendesa, M.A.D.E. and Prof. Made Antara, MS. for help, guidance and comments on the writing of this paper.

\section{References}

Alegre, J. and Cladera, M. (2009) 'Analysing the effect of satisfaction and previous visits on tourist intentions to return', European Journal of Marketing. Emerald Group Publishing Limited, 43(5/6), pp. 670-685.

http://ojs.unud.ac.id/index.php/eot
Aziz, N. A. and Ariffin, A. A. (2009) 'Identifying the relationship between travel motivation and lifestyles among Malaysian pleasure tourists and its marketing implications', International Journal of Marketing Studies, 1(2), p. 96.

Baker, D. A. and Crompton, J. L. (2000) 'Quality, satisfaction and behavioral intentions', Annals of tourism research. Elsevier, 27(3), pp. 785804.

Barker, N. H. L. and Roberts, C. M. (2004) 'Scuba diver behaviour and the management of diving impacts on coral reefs', Biological Conservation. Elsevier, 120(4), pp. 481-489.

Beggs, B. A. and Elkins, D. J. (2010) 'The influence of leisure motivation on leisure satisfaction.', LARNet-The Cyber Journal of Applied Leisure and Recreation Research. North Carolina Central University, (July).

Cheng, C.-F. and Lee, A.-H. (2011) 'The influences of relationship marketing strategy and transaction cost on customer satisfaction, perceived risk, and customer loyalty', African Journal of Business Management. Academic Journals, 5(13), p. 5199.

Chow, S. and Holden, R. (1997) 'Toward an understanding of loyalty: the moderating role of trust', Journal of managerial Issues. JSTOR, pp. 275298.

Chumpitaz Caceres, R. and Paparoidamis, N. G. (2007) 'Service quality, relationship satisfaction, trust, commitment and business-to-business loyalty', European journal of marketing. Emerald Group Publishing Limited, 41(7/8), pp. 836-867.

Correia, A., Oom do Valle, P. and Moço, C. (2007) 'Why people travel to exotic places', International Journal of Culture, Tourism and Hospitality Research. Emerald Group Publishing Limited, 1(1), pp. 45-61.

e-ISSN: 2407-392X. p-ISSN: 2541-0857 
Cropanzano, R. and Mitchell, M. S. (2005) 'Social exchange theory: An interdisciplinary review', Journal of management. Sage Publications Sage CA: Thousand Oaks, CA, 31(6), pp. 874-900.

Deci, E. L. and Ryan, R. M. (2000) 'The“" what" and" why" of goal pursuits: Human needs and the selfdetermination of behavior', Psychological inquiry. Taylor \& Francis, 11(4), pp. 227-268.

Dmitrović, T., Knežević Cvelbar, L., Kolar, T., Makovec Brenčič, M., Ograjenšek, I. and Žabkar, V. (2009) 'Conceptualizing tourist satisfaction at the destination level', International Journal of Culture, Tourism and Hospitality Research. Emerald Group Publishing Limited, 3(2), pp. 116126.

Esichaikul, R. (2012) 'Travel motivations, behavior and requirements of European senior tourists to Thailand', PASOS. Revista de Turismo y Patrimonio Cultural. Universidad de La Laguna, 10(2).

Ferdinand, A. (2002) 'Structural equation modeling dalam penelitian manajemen', Semarang: Badan Penerbit Universitas Diponegoro.

Forgas-Coll, S., Palau-Saumell, R., SánchezGarcía, J. and Callarisa-Fiol, L. J. (2012) 'Urban destination loyalty drivers and cross-national moderator effects: The case of Barcelona', Tourism Management. Elsevier, 33(6), pp. 1309-1320.

Foster, D. (1999) 'Measuring customer satisfaction in the tourism industry', in third international and sixth national research conference on quality management, Melbourne.

Fullerton, G. and Taylor, S. (2000) 'The role of commitment in service relationships', in American Marketing Association. Conference Proceedings. American Marketing Association, p. 3.
Gagné, M. and Deci, E. L. (2005) 'Selfdetermination theory and work motivation', Journal of Organizational behavior. Wiley Online Library, 26(4), pp. 331-362.

Gallarza, M. G. and Saura, I. G. (2006) 'Value dimensions, perceived value, satisfaction and loyalty: an investigation of university students' travel behaviour', Tourism management. Elsevier, 27(3), pp. 437452.

Garbarino, E. and Johnson, M. S. (1999) 'The different roles of satisfaction, trust, and commitment in customer relationships', the Journal of Marketing. JSTOR, pp. 70-87.

Gnoth, J., Bigné, J. E. and Andreu, L. (2006) 'Waiting time effects on the leisure experience and visitor emotions', Progress in Tourism Marketing. Routledge, 255.

Hair, J. F. J., Black, W. C., Babin, B. J. and Anderson, R. E. (2010) 'Multivariate Data Analysis Seventh Edition Prentice Hall'.

Hui, T. K., Wan, D. and Ho, A. (2007) 'Tourists' satisfaction, recommendation and revisiting Singapore', Tourism management. Elsevier, 28(4), pp. 965-975.

Jacoby, J. and Kyner, D. B. (1973) 'Brand loyalty vs. repeat purchasing behavior', Journal of Marketing research. JSTOR, pp. 1-9.

Jang, S. S. and Feng, R. (2007) 'Temporal destination revisit intention: The effects of novelty seeking and satisfaction', Tourism management. Elsevier, 28(2), pp. 580-590.

Joynathsing, C. and Ramkissoon, H. (2010) 'Understanding the behavioral intention of European tourists', in International Research Symposium in Service Management, pp. 938-1694. 
Kim, J., Hong, S., Min, J. and Lee, H. (2011) 'Antecedents of application service continuance: A synthesis of satisfaction and trust', Expert Systems with Applications. Elsevier, 38(8), pp. 9530-9542.

Kim, S. S., Lee, C.-K. and Klenosky, D. B. (2003) 'The influence of push and pull factors at Korean national parks', Tourism management. Elsevier, 24(2), pp. $169-180$.

Kim, T. T., Kim, W. G. and Kim, H.-B. (2009) 'The effects of perceived justice on recovery satisfaction, trust, word-ofmouth, and revisit intention in upscale hotels', Tourism Management. Elsevier, 30(1), pp. 51-62.

Lee, H.-W. and Liu, C.-H. (2009) 'The relationship among achievement motivation, psychological contract and work attitudes', Social Behavior and Personality: an international journal. Scientific Journal Publishers, 37(3), pp. 321-328.

Lee, T. H. (2009) 'A structural model to examine how destination image, attitude, and motivation affect the future behavior of tourists', Leisure Sciences. Taylor \& Francis, 31(3), pp. 215-236.

Martínez, S. C. and Guillén, M. J. Y. (2006) 'Effects of Price Promotions on Consumer Loyalty towards Travel Agencies', Progress in Tourism Marketing. Routledge, pp. 269-279.

Musa, G. (2002) 'Sipadan: a SCUBA-diving paradise: an analysis of tourism impact, diver satisfaction and tourism management', Tourism Geographies. Taylor \& Francis, 4(2), pp. 195-209.

Pepe, M. S., Abratt, R. and Dion, P. (2011) 'The impact of private label brands on customer loyalty and product category profitability', Journal of product \& Brand management. Emerald Group Publishing Limited, 20(1), pp. 27-36.
Perera, P. K. (2011) 'Marketing Forest-Based Ecotourism in Sri Lanka: Predicting The Ecotourism Behavior And Defining The Market Segment Through A Behavioral Approach'.

Raj G. Javalgi, R. and Moberg, C. R. (1997) 'Service loyalty: implications for service providers', Journal of services marketing. MCB UP Ltd, 11(3), pp. 165-179.

Ryan, R. M. and Deci, E. L. (2000) 'Selfdetermination theory and the facilitation of intrinsic motivation, social development, and well-being.', American psychologist. American Psychological Association, 55(1), p. 68.

Salegna, G. J. and Fazel, F. (2011) 'An examination of the relationships and interactions among product, brand, personal and service provider loyalty', Journal of Consumer Satisfaction, Dissatisfaction and Complaining Behavior. Consumer Satisfaction, Dissatisfaction and Complaining Behavior, 24, p. 42.

Sanchez-Franco, M. J. (2009) 'The moderating effects of involvement on the relationships between satisfaction, trust and commitment in e-banking', Journal of Interactive Marketing. Elsevier, 23(3), pp. 247-258.

Schüler, J., Sheldon, K. M. and Fröhlich, S. M. (2010) 'Implicit need for achievement moderates the relationship between competence need satisfaction and subsequent motivation', Journal of Research in Personality. Elsevier, 44(1), pp. 1-12.

Setiadi, N. J. (2010) 'Perilaku Konsumen: Perspektif kontemporer pada motif, tujuan, dan keinginan konsumen', Kencana Prenada Media, Jakarta. 
Sierra, J. J. and McQuitty, S. (2005) 'Service providers and customers: social exchange theory and service loyalty', Journal of Services Marketing. Emerald Group Publishing Limited, 19(6), pp. 392-400.

Singh, H. (2006) 'The importance of customer satisfaction in relation to customer loyalty and retention', Academy of Marketing Science, 60, pp. 193-225.

Taleghani, M., Choobeh, E. R. and Mousavian, S. J. (2011) 'The Role of Loyalty Dimensions in Customer Orientation Process For New Enterprises in Tourism Industries of Iran', Australian Journal of Business and Management Research. Australian Journal of Business and Management Research (AJBMR), 1(6), p. 143.

Um, S., Chon, K. and Ro, Y. (2006) 'Antecedents of revisit intention', Annals of tourism research. Elsevier, 33(4), pp. 1141-1158.

Ünlüönen, K., Kiliçlar, A. and Yüksel, S. (2011) 'The calculation approach for leakages of international tourism receipts: the Turkish case', Tourism Economics. SAGE Publications Sage UK: London, England, 17(4), pp. 785802.

Valle, P. O. do, Silva, J. A., Mendes, J. and Guerreiro, M. (2006) 'Tourist satisfaction and destination loyalty intention: a structural and categorical analysis', International Journal of Business Science and Applied Management. Matopoulos, Aris, 1(1), pp. 25-44.

Vallerand, R. J. (2007) 'Intrinsic and extrinsic motivation in sport and physical activity', Handbook of sport psychology, 3, pp. 59-83.

Yoon, Y. (2002) 'Development of a structural model for tourism destination competitiveness from stakeholders' perspectives'.
Yoon, Y. and Uysal, M. (2005) 'An examination of the effects of motivation and satisfaction on destination loyalty: a structural model', Tourism management. Elsevier, 26(1), pp. 45-56.

Yüksel, A. and Yüksel, F. (2007) 'Shopping risk perceptions: Effects on tourists' emotions, satisfaction and expressed loyalty intentions', Tourism management. Elsevier, 28(3), pp. 703713.

Yuksel, A., Yuksel, F. and Bilim, Y. (2010) 'Destination attachment: Effects on customer satisfaction and cognitive, affective and conative loyalty', Tourism management. Elsevier, 31(2), pp. 274-284. 